\title{
ANALISIS STRATEGI MARKETING MIX DAN VOLUME PENJUALAN PADA USAHA SAOS SAMBAL GANDA SARI MUARA BULIAN
}

\author{
Jasasila $^{1}$
}

\begin{abstract}
This study aims to determine the development of sales volume on the business of Sambal Ganda Sari Muara Bulian, to know the application of marketing mix strategy on Saos Sambal Ganda Sari Muara Bulian and to analyze Marketing Mix Strategy and Sales Volume on Saos Sambal Ganda Sari Muara Bulian. In this study the authors use descriptive and inductive data collection methods. To complete the accuracy of the results of research then in this study the authors use literature study, where the authors look for sources of information through writing both in the form of journals and articals associated with the research topic undertaken. From the analysis result, it can be seen that in general the product of sambal sauce has a good sales growth, where in the year of 2013 there is an increase of sales volume $13.65 \%$, so also in the year 2014 there was an increase of $15.95 \%$, significant sales volume growth occurred in 2015 where the increase reached $20.42 \%$ compared to the previous year, although in 2016 the development of Saal Sambal Ganda Sari Muara Bulian sales was not as much as the previous year which was $13.65 \%$ but the sales volume increased by 41,000 units. Strategy Marketing Mix on the road Strategy by saos sambal Ganda Sari business consists of, product strategy, Pricing Strategy, Promotion Strategy and Promotional Channel Strategy

Keywords: Strategy; Marketing Mix; sales
\end{abstract}

\section{PENDAHULUAN}

Pada umumnya setiap usaha yang dijalankan bertujuan untuk meningkatkan volume penjualan, mempertinggi daya aing dan tentunya meminimalkan biaya produk yang dikeluarkan untuk mencapai hasil keuntungan yang maksimal. Keuntungan yang didapat mencerminkan keberhasilan suatu usaha dalam melaksanakan manajemen dan menjaga kelansungan usaha yang dilakukan, untuk memperoleh laba yang maksimal tentu bukanlah hal yang mudah bagi sebuah usaha, salah satu yang mempegaruhi dari keberhasilan keuntungan tersebut adalah pemasaran. Konsep pemasaran saat ini telah terjadi perubahan besar dimana tidak lagi berorientasi pada produk yang dihasilkan tetapi beralih kepada konsumen. Akibatnya suatu usaha tidak hanya mampu memenuhi kebutuhan konsumen tetapi harus juga dapat meuaskan konsumen, sehingga muncul kompetisi antar pelaku usaha. Pemasaran merupakan salah satu ilmu ekonomi yang sangat mempengaruhi keberhasian suatu usaha untuk bisa bertahan didalam pangsa pasar, oleh karenanya dibutuhkan strategi yang dapat memberikan pengaruh untuk menentukan berhasil atau tidaknya dalam memasarkan produk, apabila strategi pemasaran yang dilakukan sebuah usaha tersebut mampu memasarkan produknya dengan baik maka keuntungan yang didapat akan maksimal.

Dimasa persaingan yang sangat kompetitif ini, antara perusahaan saling membutuhkan kerja sama untuk memasarkan produk yang dibutuhkan dalam hal ini adalah menjalin kerja sama untuk menata saluran distribusi dan perusahaan membutuhkan kerja sama untuk memasarkan produk yang dibutuhkan saluran distribusi terdiri dari lembaga, badan, atau perorangan untuk dapat bekerja sama

${ }^{1}$ STIE Graha Karya Muara Bulian 
agar produk dapat mudah samapai dan diperoleh oleh konsumen dan dapat dibutuhkan tepat pada waktunya kerja sama ini akan mempengaruhi kerja perusahaan untuk mengatur kendali produk. Untuk mampu menciptakan loyalitas pelanggan tersebut, para pengembang perlu memiliki suatu strategi pemasaran yang jitu dalam memasarkan produknya, karena strategi pemasaran juga merupakan alat fundamental yang direncanakan untuk mencapai tujuan perusahaan dengan mengembangkan keunggulan bersaing yang digunakan untuk melayani pasar sasaran (Tull \& Kahle dalam Tjiptono 1997). Dalam mengembangkan bisnis makanan, pengusaha tidak cukup hanya mengandalkan barang dan mutu produk yang dijual. Salah satu bentuk strategi pemasaran yang mampu mendukung dalam memasarkan produk untuk menciptakan kepuasan konsumen adalah penggunaan marketing mix (bauran pemasaran) yang meliputi product, price, promotion, dan physical evidence atau place (Pawitra 1993). Dengan demikian, faktor yang ada dalam bauran pemasaran (marketing mix) merupakan variabel-variabel yang diharapkan mampu menciptakan kepuasan konsumen, atau dengan kata lain variabel-variabel tersebut akan mempengaruhi kepuasan konsumen dalam membeli suatu produk. Kepuasan pelanggan akan berimbas kepada loyalitas pelanggan, sehingga usaha yang dibangun akan terus bertahan dan berkembang. Sebuah usaha dikatakan berkembang dan mampu bertahan jika mempunyai indikator awal yaitu penjualan yang bagus, atau dengan kata lain penjualan yang meningkat dari waktu ke waktu. Penjualan adalah suatu usaha yang terpadu untuk mengembangkan rencana-rencana strategis yang diarahkan pada usaha pemuasan kebutuhan dan keinginan pembeli, guna mendapatkan penjualan yang menghasilkan laba (Marwan, 1991). Penjualan merupakan sumber hidup suatu perusahaan, karena dari penjualanlah maka diperoleh laba. Laba digunakan untuk mengembangkan usaha dan mempertahankan usaha.

Salah satu usaha yang melaksanakan marketing mix adalah usaha Saos Sambal Ganda sari Muara Bulian, dalam kegiatan memasarkan produknya mengalami peningkatan hal ini terlihat dari tabel volume penjualan selama periode $2012-2016$.

\begin{tabular}{lc}
\hline Tahun & Volume Penjualan (unit) \\
\hline 2012 & 136.800 \\
2013 & 152.400 \\
2014 & 173.200 \\
2015 & 200.800 \\
2016 & 241.800 \\
\hline
\end{tabular}

Dari Konsep marketing mix yang dijalankan oleh usaha Saos Sambal Ganda Sari Muara Bulian ini yaitu pemahaman atas kebutuhan, keinginan serta perilaku pelanggan, untuk itu harus dapat mendengarkan suara pelanggan agar dapat memudahkan menentukan kebutuhan pembeli dan menetapkan cara merancang serta menetapkan tawaran yang dapat memuaskan kebutuhan pelanggan, hasil produksi yang baik serta kualitas yang juga semakin baik. Dari data peningkatan penjualan ditengah persaingan yang cukup ketat sekarang ini usaha yang dijalankan harus mampu bertahan bahkan berkembang dengan baik, berdasarkan uraian diatas maka penulis tertarik untuk melakukan penelitian yang diberi judul : Analisis Marketing Mix dan Volume Penjualan Pada Usaha Saos Sambal Ganda Sari Muara Bulian. 
Dari latar belakang diatas dapat dirumuskan sebuah masalah penelitian, yaitu Bagaimana perkembangan dan strategi marketing mix hubungannya dengan volume penjualan pada usaha Saos Sambal Ganda Sari Muara Bulian, sedangkan tujuan dari penelitian ini adalah : 1) Untuk mengetahui perkembangan volume penjualan pada usaha Saos Sambal Ganda Sari Muara Bulian. 2) Untuk mengetahui penerapan strategi marketing mix pada usaha Saos Sambal Ganda Sari Muara Bulian. 3) Untuk menganalisis Strategi Marketing Mix dan Volume Penjualan pada Usaha Saos Sambal Ganda Sari Muara Bulian

\section{METODE PENELITIAN}

Dalam penelitian ini penulis menggunakan metode pengumpulan data diskriptif dan induktif. Metode deskriptif adalah metode yang bertujuan untuk menggambarkan sifat sesuatu yang tengah berlangsung pada saat riset dilakukan dan memeriksa sebab-sebab dari suatu gejala terentu. Penulis melakukan penelitian lansung pada objek penelitian yaitu usaha Saos Sambal Ganda Sari Muara Bulian, melakuan observasi dan wawancara lansung. Berdasarkan fakta dan data yang dikumpulkan, kemudian di susun secara sistematis selanjutnya di analisis untuk memperoleh kesimpulan. Analisis induktif adalah metode penelitian yang bertujuan untuk menganalisis data dengan cara pengujian hipotesa penelitian khususnya yang ada hubungan dengan masalah yang akan dibahas untuk mendapatkan kesimpulan. Untuk melengkapi keakuratan hasil peneitian maka dalam penelitian ini penulis menggunakan studi kepustakaan, dimana penulis mencari sumber informasi melalui tulisan baik dalam bentuk jurnal maupun artikal yang berhubungan dengan topik penelitian yang dilakukan.

Untuk menghitung perkembangan biaya pada usaha Saos Sambal Ganda Sari Muara Bulian maka penulis menggunakan rumus :

Perkembangan $=\frac{\mathrm{VP}_{\mathrm{a}}-\mathrm{VP}_{\mathrm{a}-1}}{\mathrm{VP}_{\mathrm{a}-1}}$

Dimana :

$\mathrm{VP}_{\mathrm{a}}=$ Volume Penjualan tahun analisis

$\mathrm{VP}_{\mathrm{a}-1}=$ Volume Penjualan tahun sebelumnya

HASIL DAN PEMBAHASAN

Perkembangan Volume Penjualan pada Usaha Saos Sambal Ganda Sari Muara bulian.

Pemasaran memegang peranan penting dalam setiap dunia usaha karena dengan lancarnya pemasaran maka volume penjualan akan dapat ditingkatan, maka keuntungan akan dapat diperoleh. Begitu pula dengan Usaha Saos Sambal Ganda Sari Muara Bulian, untuk mngetahui lancar tidaknya volume penjualan tersebut dapat dilihat dari keadaan penjualannya. Lebih jelassnya dapat dilihat pada tabel dbawah ini : 


\begin{tabular}{ccccc}
\hline Tahun & \multicolumn{2}{c}{ Unit Penjualan } & Jumlah & Pemasan \\
& Botol & $\begin{array}{c}\text { Kemasan } \\
\text { Plastik }\end{array}$ & $\begin{array}{c}\text { Penjualan } \\
\text { Perkembangan }\end{array}$ & \\
\hline 2012 & 50.400 & 86.400 & 136.800 & \\
2013 & 50.400 & 108.000 & 152.400 & $13,65 \%$ \\
2014 & 43.200 & 130.000 & 173.200 & $15,94 \%$ \\
2015 & 28.800 & 172.800 & 200.800 & $20,42 \%$ \\
2016 & 28.200 & 212.000 & 241.800 & $13,65 \%$ \\
Rata-rata & $\mathbf{4 0 . 2 0 0}$ & $\mathbf{1 4 1 . 8 9 0}$ & $\mathbf{1 8 1 . 0 0 0}$ & $15,35 \%$ \\
\hline
\end{tabular}

Dari tabel diatas terlihat bahwa terjadi peningkatan volume penjualan dari tahun 2012 samai dengan tahun 2016, dari dua kemasan yang diproduksi terlihat kemasan plastik mendapatkan unit penjualan yang lebih besar jika dibandingkan dengan kemasan botol, tetapi secara umum produk saos sambal ini mengalami perkembangan penjualan yang baik, dimana pada tahun 2013 terjadi peningkatan volume penjualan sejumlah $13,65 \%$ dibandingkan dengan volume tahun sebelumnya, begitu juga pada tahun 2014 terjadi peningkatan sebesar 15,95\% dari volume penjualan tahun 2013, perkembangan volume penjualan yang signifikan terjadi pada tahun 2015 dimana peningkatannya mencapai 20,42\% dibandingkan dengan tahun sebelumnya, walaupun pada 2016 perkembangan penjualan Saos Sambal Ganda Sari Muara Bulian tidak sebesar pada tahun 2015 yaitu sebesar $13,65 \%$ tetapi volume penjualan meningkat sejumlah 41.000 unit. Dari peningkatan volume penjualan tersebut didapat rata-rata jumlah penjualan Saos Sambal Ganda Sari Muara Bulian dari tahun 2012 - 2016 adalah sebesar 181.000 unit, atau terjadi perkembangan rata-rata sebesar $15,35 \%$.

\section{Strategi Marketing Mix pada Usaha Saos Sambal Ganda Sari Muara Bulian}

\section{Srategi Produk}

Dilihat dari Aspek Strategi produk, keputusan mengenai jenis dan desain produk yang di produksi Saos Ganda Sari Muara Bulian, memperhatikan selera konsumen. Dari hasil observasi lapangan Saos Sambal Ganda sari Muara Bulian, menggunakan bahan-bahan yang berkualitas, tidak mengandung perasa buatan dan dibuat oleh tenaga-tenaga profesional dalam bidangnya. Hal ini terlihat dari bahan - bahan yag digunakan dalam pembuatan saos ini, Pelaku usaha lansung membeli dari pasar seperti : tomat, cabai, baeang putih, tepung tapioka, cuka, pewarna makanan yang higienis,sakarin, bemzoate yang merupakan bahan pilihan untuk mempertahan kualitas produk.

Semakin baik kualitas produk yang diberikan maka konsumen akan semakin berminat melakukan pembelian, Untuk itu, sudah menjadi suatu keharusan bagi usaha saos sambal ganda sari untuk memberikan kualitas produk yang terbaik. Produk saos yang dihasilkan ini mempunyai target utama konsumen yaitu para usaha yang bergerak dibidng kuliner. Disamping itu untuk menjada kepercayaan konsumen terhadap produk maka secara rutin dilakukan pengawasan dan uji laboratorium dari dinas kesehatan Kabupaten Batanghari dan BPOM serta sebagai salah satu upaya untuk mencapatkan sertifikat halal dari MUI. 


\section{Strategi Harga}

Harga merupakan satau-satunya unsur marketing mix yang memberikan pemasukan atau pendapatan bagi usaha. Penempatan harga dipengaruhi oleh faktor internal dan eksternal. Faktor internal tersebut meliputi tujuan perusahaan, strategi bauran pemasaran dan biaya yag dikeluarkan selama proses produksi. Faktor eksternal meliputi ; pasar, persaingan dan unsur lingkungan lainnya. Strategi harga yang dilakukan oleh usaha saos sambal Ganda Sari Muara Bulian ini adalah dengan menempatkan harga yang paling tepat dalam arti dapat memberikan keuntungan yang diinginkan agar tujuan jangka pendek dan tujuan jangka panjang dari perusahaan dapat tercapai. Harga setiap produk sangat mempertimbangkan sebaik mungkin dengan mengatur baiay produksi, keuntungan yang ingin diambil serta biaya pemasarannya seperti biaya proses distribusi barang hingga sampai ketangan konsumen, jumlah biaya produksi + Laba yang diinginkan + Biaya Distribusi $=$ Harga Jual. Setelah perusahaan memutuskan produk yang akan dijual, termasuk intensitas adapatasi yang akan digunakan dan segmen pasar yang menjadi pasar sasaran. Perusahaan sebaiknya merumuskan kebijakan penetapan harga yang akan digunakan karena setiap tindakan yang akan dilakukan konsumen dalam melakukan pembelian selalu didasarkan pada harga produk yang akan dibeli. Dengan jauhnya jarak anatara produsen dan konsumen dipasar, membuka kemungkinan terjadinya peningkatan harga dipasar lokal tentu lebih tinggi dibandingkan harga ditempat barang tersebut diproduksi, hal tersebut terjadi karena adanya tambahan beban biaya transportasi yang besar dan biaya distribusi. Jika dilihat volume penjualan daris egi harga penurunan volume penjualan kemasan botol yang terjadi 20122016 diperkirakan karena keterjangkauan / daya beli masyarakat. Masyarakat lebih tertarik pada kemasan plastik karena harganya relatif lebih murah jika dibandingkan dengan kemasan botol. Meskipun terjadi kenaikan pada harga bahan baku, pemilik usaha tidak menaikkan harga jual produk tersebut.

\section{Srategi Promosi}

Dalam melakukan strategi promosi yang dilakukan oleh usaha saos sambal Ganda Sari Muara Bulian, berdasarkan hasil observasi penelitian yang dilakukan, promosi untuk kemasan botol dilakukan dengan cara man to man atau dari mulut kemulut yang dilakukan oleh konsumen satu dengan konsumen yang lain. Sedangkan untuk kemasan plastik pihak perusahaan melakukan promosi dengan memasang spanduk dan menyebarkan brosur. Dari segi promosi dilihat dari volume penjualan pada tahun 2015 khusus untuk kemasan botol mengalami penurunan, ini diakibatkan oleh oleh kurangnya promosi melalui media masa atau dalam bentuk lainnya sehingga masyarakat tidak mengetahui adanya produk kemasan botol ini dipasaran tetapi sebaliknya untuk kemasan plastik mengalami peningkatan yang cukup siginifikan, karena promosi sudah dijalankan walupun hanya dalam bentuk spanduk dan brosur.

\section{Strategi Saluran Promosi}

Dari hasil wawancara dengan pemilik usaha saos sambal ganda sari, bahwa proses distribusi menggunakan saluran produksi One Level yaitu dari Produsen - Pengecer - Konsumen, disebut one level atau saluran semi lansung, pada tahap ini produsen telah menggunakan perantara yaitu pengecer dan kemudian ke konsumen terakhir, dan strategi distribusi yang digunakan oleh usaha saos sambal ini adalah Sistem 
Strategi Instensif, dimana strategi ini digunakan oleh perusahaan jika digunakan pada daerah yang sama, perusahaan menemapatkan produknya, diberbagai distribusi atau pengecer dalam jumlah banyak ksehingga dapat dengan mudah dijangkau oleh konsumen dan kepuasan konsumen akan dirasakan. Pemasaran yang dilakukan oeh usaha saos sambal ganda sari tidak hanya diwilayah produksi saja atau daerah Muara Bulian tetapi sudah menjangkau daerah kabupaten kota yang ada di propinsi Jambi. Keseluruhan strategi pemasaran yang dilaksanakan oleh Usaha Saos Sambal ganda sari melalui program bauran pemasarannya adalah untuk mencapai tujuan perusahaan khususnya pemasarannya yaitu menambah konsumen, memertahankan pelanggan danmeningkatkan volume penjualan sehingga dengan kegiatan tersebut perusahaan akan mampu memperoleh laba yang dapat digunakan untuk menjaga kelangsuangan hidup perushaan untuk jangka panjang. Pola distribusi yang dilakukan oleh usaha Saos Sambal Ganda Sari ternaya belum dapat meningkatkan penjualan secara siginifikan. Hal ini dikarenakan pola distribusiknya belum merata keseluruh pasaran, sehingga manfaat produk belum dirasakan oleh masayarakat secara keseluruhan.

\section{Analisis Strategi Marketing Mix dan Volume Penjualan Pada Usaha Saos Sambal Ganda Sari Muara Bulian}

Dinamika persaingan binis yang semakin ketat membawa implikasi pada upaya yang berkesinambungan agar produk dapat sampai ketangan konsumen diwaktu yang tepat, tempat yang tepat dan harga yang tepat, sehingga distributor memiliki posisi yang strategis dalam upaya membawa perusahaan kearah yang lebih baik. Strategi pemasaran merupakan pegangan bagi perusahaan agar mempunyai keunggulan dalam persaingan pasar, sekaligus mencari kecocokan antara kemampuan internal perusahaan dalam hal ini menjual produk ke konsumen dengan peluang eksternal yang ada dipasar yaitu pemebeli potensial yang menyukai produk yang dijual tersebut. Dengan demikian haruslah diketaui karakteristik pasar serta struktur pasar yang dihadapi. Hal ini dapat dicapai dengan pengembangan dan menyajikan marketing mix yang diarahkan pada pasar sasaran y ang dipilih. Konsep marketing mix biasanya dijadikan keunggulan bersaing dngan produk yang sejenis perusahaan lainnya, yang merupakan keunggulan dalam produk (product), harga (price), promosi (promotion), tempat (tempat). Hal - hal inilah yang perlu diperhatikan perusahaan agar dapat memasuki persaingan dipasar yang semakin ketat. Konsep marketing mix ini biasanya digunakan oleh perusahaan untuk mencipatakan kepuusan pembelian konsumen atas produk yang ditawarkan oleh produsen untuk menciptakan keputusan pembelian produk yang ditawarkan oleh produsen serta mengukur bagaimana pengaruh dari marketing mix tersebut terhadap keputusan pembelian produk yang diambil oleh konsumen.

Menyadari akan pentingnya pelanggan dalam menentukan kesusksesan suatu usaha maka usaha saos sambal Ganda Sari Muara Bulian sebagai salah satu UKM menggunakan startaegi marketing mix semaksimal mungkin dalam usahanya untuk menciptakan keputusan pembelian konsumen terhadap produk yang ditawarkan khususnya produk saos sambal yang menjadi produk utama, agar usahanya tersebut dapat diterima dengan baik dipasaran. Untuk menganalisis startegi mix yang digunakan oleh usaha saos sambal Ganda Sari terhadap volume penjualan terlihat sejak tahun 2012-2016 secara keseluruhan terjadi kenaikaan volume penjualan ratarata pada kemasan botol sebesar 40.200 kemasan, sedangan kenaikan volume penjualan rata-rata kemasan plastik adalah 141.890 kemasan, rata-rata jumlah 
penjualan kedua kemasan tersebut adalah 181.000 kemasan dengan persentase kenaikan rata-rata sebesar $15,24 \%$. Kenaikan rata-rata tersebut dipengaruhi oleh kebijakan dalam marketing mix dimana dari sisi produk kemasan botol dan plastik pada tahun 2012 masih menggunakan merk paten, sedangkan tahun 2013 usaha saos sambal ini telah membuat kemasan sendiri dengan design yang baru dilengkapi dengan muatan kompisisi, sertifikat halal dari MUI serta badan kesehatan dan BPOM. Pada sisi harga meskipun dari bahan baku pemuatan saos mengalami kenaikan, akan tetapi harga jual produk saos sambal Ganda Sari Muara Bulian masih sama seperti tahun sebelumnya atau tidak mengalami kenaikan harga. Disisi lain harga produk dari pesaing memang cukup kompetitif dipasaran, akan tetapi saat bahan baku mengalami kenaikan beberapa usaha saos sambal juga menaikkan harga jual produknya untuk menekan biaya produksi, meskipun demikian usaha saos sambal ganda sari tidak menaikkan harga jualnya bahkan untuk kemasan plastik usaha saos sambal ganda sari memberikan potongan harga.

Dari sisi promosi pada tahun 2013 usaha saos Ganda Sari sudah menganggarkan dana untuk kegiatan promosi baik dari media cetak, seperti surat kabar maupun media elektronik radio, karena sebelumnya hanya mengandalkan promosi melalui spanduk dan brosur, sedangkan dari sisi distribusi usaha saos Ganda Sari pemasarannya sudah menjangkau sebagian wilayah Kabupaten/Kota di propinsi Jambi seperti, Sarolangun, Tebo, Bungo dan Kota Jambi. Keseluruhan strategi pemasaran yang dilaksanakan oleh usaha Saos Sambal Ganda Sari melalui program bauran pemasarannya adalah untuk mencapai tujuan perusahaan khususnya sasaran pemasarannya yaitu menambah konsumen, mempertahankan pelanggan dan meningkatkan volume penjualan sehinga dengan itu usaha saos sambal akan memperoleh kuntungan yang maksimal.

Untuk sisi jenis kemasan produk dapat dilihat kemasan botol mengalami penurunan volume penjualan ditahun 2015 dan 2016, penurunan ini juga dipengaruhi oleh kebijakan marketing mix yaitu :

1. Dari segi produk usaha saos Ganda Sari telah membuat kemasan plastik yang lebih kecil, sehingga mendorong peningkatan volume penjualan terutama konsumen yang memerlukan saos yang praktis sehingga ada perubahan selera konsumen dari kemasan botol kekemasan plastik.

2. Demikian juga dari segi harga produk saos sambal Ganda Sari dengan kemasan plastik lebih murah dibandingkan dengan produk kemasan botol, mengakibatkan volume penjualan terhadap kemasan botol terjadi penurunan.

3. Untuk sisi promosi juga mempengaruhi penurunan volumen penjualan kemasan botol, karena promosi yang dilakukan hanya melalui mulut kemulut besa dengan produk kemasan plastik yang sudah menggunakan spanduk dan brour dalam pelakasanaan promosinya.

4. Sedangkan dari sisi distribusi tidak mempunyai pengaruh yang signifikan, tetapi dikarenakan permintaan terhadap kemasan plastik lebih banyak maka distribusi produk kemasan botol sedikit terganggu.

\section{SIMPULAN}

Secara umum produk saos sambal ini mengalami perkembangan penjualan yang baik, dimana pada tahun 2013 terjadi peningkatan volume penjualan sejumlah $13,65 \%$ dibandingkan dengan volume tahun sebelumnya, begitu juga pada tahun 2014 terjadi peningkatan sebesar 15,95 \% dari volume penjualan tahun 2013, perkembangan volume penjualan yang signifikan terjadi pada tahun 2015 dimana 
peningkatannya mencapai $20,42 \%$ dibandingkan dengan tahun sebelumnya, walaupun pada 2016 perkembangan penjualan Saos Sambal Ganda Sari Muara Bulian tidak sebesar pada tahun 2015 yaitu sebesar 13,65 \% tetapi volume penjualan meningkat sejumlah 41.000 unit. Dari peningkatan volume penjualan tersebut didapat rata-rata jumlah penjualan Saos Sambal Ganda Sari Muara Bulian dari tahun 2012 - 2016 adalah sebesar 181.000 unit, atau terjadi perkembangan rata-rata sebesar 15,35\%. Strategi Marketing Mix yang dijalan Strategi oleh usaha saos sambal Ganda Sari terjadi dari, strategi produk dimana keputusan mengenai jenis dan desain produk yang di produksi Saos Ganda Sari Muara Bulian, memperhatikan selera konsumen. Kemudian Strategi Harga, harga merupakan satu-satunya unsur marketing mix yang memberikan pemasukan atau pendapatan bagi usaha. Penempatan harga dipengaruhi oleh faktor internal dan eksternal. Faktor internal tersebut meliputi tujuan perusahaan, strategi bauran pemasaran dan biaya yag dikeluarkan selama proses produksi. Faktor eksternal meliputi ; pasar, persaingan dan unsur lingkungan lainnya. Strategi harga yang dilakukan oleh usaha saos sambal Ganda Sari Muara Bulian ini adalah dengan menempatkan harga yang paling tepat dalam arti dapat memberikan keuntungan yang diinginkan agar tujuan jangka pendek dan tujuan jangka panjang dari perusahaan dapat tercapai. Disamping ada Srategi Promosi dalam melakukan strategi promosi usaha saos sambal Ganda Sari Muara Bulian, berdasarkan hasil observasi penelitian yang dilakukan, promosi untuk kemasan botol dilakukan dengan cara man to man atau dari mulut kemulut yang dilakukan oleh konsumen satu dengan konsumen yang lain. Sedangkan untuk kemasan plastik pihak perusahaan melakukan promosi dengan memasang spanduk dan menyebarkan brosur. Sedangkan Strategi Saluran Promosi dari hasil wawancara dengan pemilik usaha saos sambal ganda sari, bahwa proses distribusi menggunakan saluran produksi One Level yaitu dari Produsen Pengecer - Konsumen, disebut one level atau saluran semi lansung, pada tahap ini produsen telah menggunakan perantara yaitu pengecer dan kemudian ke konsumen terakhir, dan strategi distribusi yang digunakan oleh usaha saos sambal ini adalah Sistem Strategi Instensif, dimana strategi ini digunakan oleh perusahaan jika digunakan pada daerah yang sama, perusahaan menemapatkan produknya, diberbagai distribusi atau pengecer dalam jumlah banyak ksehingga dapat dengan mudah dijangkau oleh konsumen dan kepuasan konsumen akan dirasakan.

\section{DAFTAR PUSTAKA}

Ardianto Eka, 2000, Pengukuran Persepsi Kualitas Layanan, Contoh Perjalanan sebuah Proses Penelitian, Forum Manajemen Prasetya Mulya tahun ke 13

Kotler, Philip, AB. Susanto, 2000. Manajemen Pemasaran di Indonesia, Buku 2, Salemba Empat.

Bagus Tri Purnomo, (2005), Pengaruh Variabel-Variabel Promotional Mix Terhadap volume Penjualan Pada PT. Daya Manunggal Di Salatiga. Skripsi

Basu Swastha DH, Irawan MBA. 2005. Manajemen Pemasaran Modern. Yogyakarta : Liberty

Rina Rachmawati, 2011. Peranan Bauran Pemasaran (Marketing Mix) terhadap Peningkatan Penjualan (Sebuah Kajian terhadap Bisnis Restoran), Jurnal Kompetensi Teknik Vol. 2, No. 2, Mei 2011

Emmy Indrayani, 2008, “Loyalitas Merek Sebagai Dasar Strategi Penentuan Harga”, Jakarta: Jurnal Fakultas Ekonomi Gunadarma 
Rina Rachmawati, 2011. Peranan Bauran Pemasaran (Marketing Mix) terhadap Peningkatan Penjualan (Sebuah Kajian terhadap Bisnis Restoran), Jurnal Kompetensi Teknik Vol. 2, No. 2, Mei 2011

Zulmi Nur Manik, 2015. Pengaruh Bauran Pemasaran terhadap volume penjualan Notebook merk Acer Pada CV. Galaksi Komputer Samarinda, E-jurnal Ilmu Ekonomi Bisnis 2015, ISSN 2355-5408,ejournal.adbisnis.fisip-unmul.ac.id 